\title{
Immunohistochemical assessment of the tumour-associated epitopes CD44v6 and E48 in tumour-free lymph nodes from patients with squamous cell carcinoma in the head-neck region
}

\author{
Eva-Maria Fabricius ${ }^{\mathrm{a}, *}$, Michael Guschmann ${ }^{\mathrm{b}}$, \\ Angelika Langford ${ }^{\mathrm{a}}$, Berthold Hell ${ }^{\mathrm{a}}$ and \\ Jürgen Bier ${ }^{\mathrm{a}}$

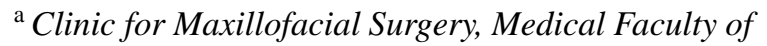 \\ the Humboldt University of Berlin, Charité, Campus \\ Virchow Hospital, Berlin, Germany \\ ${ }^{\mathrm{b}}$ Institute of Pathology, Medical Faculty of the \\ Humboldt University of Berlin, Charité, Campus \\ Virchow Hospital, Berlin, Germany
}

Received 26 June 1999

Accepted 28 February 2000

We examined immunohistochemically 370 tumour-free lymph nodes from 41 patients with a head and neck squamous cell carcinoma (HNSCC) to clarify whether the tumour-associated epitopes CD44v6 and E48 are suitable for adjuvant postoperative immunotherapy. All the positively immunostained cells found were single cells.

CD $44 \mathrm{v} 6^{+}$cells were found in $55 \%$ of the lymph nodes, with their numbers increasing in $\mathrm{pN}>0$-patients (62\%). Only $\mathrm{pN}>0$-patients had abundant to massive $\mathrm{CD} 44 \mathrm{v} 6^{+}$cells. A comparison with mononuclear cells in lymphatic tissue from control patients suggested a similarity with activated Tcells. In the 41 cancer patients there were significantly fewer lymph nodes with $\mathrm{E} 48^{+}$cells $(11 \%)$, but the number of $\mathrm{E} 48^{+}$ cells increased in $\mathrm{pN}>1$-patients $(29 \%)$ with predominantly abundant $\mathrm{E} 8^{+}$cells. We conclude from the comparison with the epithelial marker EMA that the $\mathrm{E} 48^{+}$single cells are epithelial in origin. Only a specific E48 peptide sequence ap-

\footnotetext{
${ }^{*}$ Correspondence to: Dr. rer. nat. Eva-Maria Fabricius, Medical Faculty of the Humboldt University of Berlin, Charité, Campus Virchow Hospital, Clinic for Maxillofacial Surgery, Augustenburger Platz 1, D-13353 Berlin, Germany. Tel.: 030/450 55398; Fax: 030/450 55901/450 55918; E-mail: eva-maria.fabricius@charite.de.
}

pears suitable for adjuvant immunotherapy in patients with head-neck tumours.

Keywords: Carcinoma-free lymph nodes, CD44v6, E48, immunohistochemistry, APAAP

\section{Introduction}

Squamous cell carcinomas of the head and neck tend to recurrence and secondary tumours. Worldwide, fewer than $50 \%$ of these patients survive disease five years or longer [54]. For the postoperative therapy it is crucial to detect any disseminated carcinoma cells $[2,3$, $24,30,51,53,55]$. Adjuvant radio-chemotherapy targets only cells which are in the process of proliferation and division. The majority of the disseminated carcinoma cells may be non-proliferative $\left(\mathrm{G}_{0}\right.$ phase $)$ and therefore escape the effects of this therapy $[23,51,53]$. This has prompted a search on the one hand for methods to detect disseminated cells in tumour free lymph nodes in patients with head-neck tumours and on the other hand for suitable immunological therapies to eliminate them $[2,3,11,12,24,38,52]$.

Our purpose is to choose a target epitope for an adjuvant immunotherapy with the aid of an immunohistochemical characterization of head-neck tumours. Investigations up to now of primary tumours and lymph node metastases have achieved a good presentation with the help of monoclonal antibodies against the tumour associated markers CD44v6 and E48 [26,27]. We demonstrated both epitopes on the carcinoma cells on every primary tumour and in lymph node metastases, most frequently on pG1 tumours and significantly down-regulated on pG3 tumours. 
CD44v6 is a splice variant of the ubiquitous adhesion molecule CD44, which is considered as a metastasis marker for certain tumours $[31,32]$ and can also be used to characterize among others, tumours of the head and neck region [34-36,57,67]. E48 was isolated from a head-neck tumour $[62,63,68]$. Research to date has found E48 only in normal and malignant keratinocytes, in squamous cell carcinomas and transitional epithelia [6,68]. Antibodies against CD44v6 (viz U36 [34]) and E48 are already being successfully applied in radio/immunoscintigraphy and in the radio/immunotherapy of head-neck tumours [8-10,25, 34].

Since the lymphogenic dissemination of cancer cells is crucial in carcinoma metastasis, we subjected all extirpated tumour free lymph nodes from 41 head-neck tumour patients to an immunohistochemical examination using the monoclonal antibodies against CD44v6 and E48. With these antibodies we had examined the primary tumours and their lymph node metastases in previous studies $[26,27]$. To elucidate the results, we also used various other antibodies against epithelial epitopes and against mononuclear cells. We compared the findings in tumour-free lymph nodes from our 41 head neck tumour patients and with these lymphatic tissues from non-tumour control patients (normal and inflamed lymphatic tissue such as spleen, tonsils and lymph nodes from other diseases).

\section{Material and methods}

\subsection{Patients}

From 41 head and neck tumour patients in our clinic from 1994 to 1997, we examined all 370 surgically extirpated lymph nodes located close to a primary squamous cell carcinoma. These lymph nodes had been histopathologically determined to be without carcinoma. 34 of the patients were men (average age 56 years) and 7 women (average age 67 years). Five additional lymph nodes from 4 of these patients, which according to routine histopathology were free of metastases, had to be evaluated separately (Table 1), so that our study proper comprised 370 carcinoma-free lymph nodes. The patients had received neither radio- nor chemotherapy preoperatively. The lymph nodes examined were extirpated on the same day as the primary tumours. The patients' further course of disease (recurrence, secondary tumour, death) was correlated with the CD44v6 and E48 findings in the tumour-free lymph nodes. To verify our findings, we selected archival lymphatic tissues from 30 control patients without malignant tumours: Table 2

\subsection{Tissue samples}

Immediately after the surgical removal of the lymph node from head neck tumour patients, its position was marked and documented. The lymph nodes were fixed in $10 \%$ neutral formalin, embedded in paraffin and cut to 5 micron thick paraffin sections. From the lymphatic control tissue, also embedded in paraffin, sections were made using the same technique. Prior to immunohistochemical staining the sections were preincubated overnight at $56^{\circ} \mathrm{C}$, rehydrated and prepared for antigen demasking: for monoclonal antibodies CD44v6 by microwave treatment in an acidic milieu, for E48 by treatment in an alkaline trypsin solution [26]. The preparation of the other monoclonal antibodies used for comparison is shown in Table 3.

\subsection{Immunohistochemical examination}

\subsubsection{Immunohistochemical examination of stained single cells in the tumour-free lymph nodes}

Immunohistochemical evaluation was performed using APAAP [20] with the Universal DAKO APAAPKit (Denmark). Endogenous enzyme activity was inhibited by adding levamisol (DAKO). We used $10 \%$ AB serum (BIOTEST AG) in DAKO antibody thinner for blocking, both for the primary antibodies and for the negative control serum. The monoclonal antibody E48 (CENTOCOR B.V., Leiden, The Netherlands) was diluted to $1: 10000$, the monoclonal antibody CD44v6 clone VFF-18 (BENDER, Austria) to $1: 100$. The dilution of the other monoclonal antibodies used for comparison is shown in Table 3. All primary antibodies were incubated at room temperature for 60 minutes.

Per lymph node three sections were immunostained by each antibody and evaluated. To achieve an immunohistochemical evaluation of the immunoreagents, specimens from normal facial skin were investigated as positive controls and normal mouse sera as negative controls. All the immunohistochemical results undergoing this analysis were examined by the same pathologist.

We first investigated the percentage of carcinomafree lymph nodes with $\mathrm{CD} 44 \mathrm{v} 6^{+}$or $\mathrm{E} 48^{+}$cells. Then we estimated the number of immunostained CD44v6 and/or E48 cells per visual field in the lymph nodes (magnification $200 \times$ ). The average count per lymph node was documented. Tumour-free lymph nodes with solitary stained single cells only, or with scattered distribution of positive single cells, were recorded as $1+$. Abundant to massive numbers of stained single cells per visual field were rated as $2+$. 
Table 1

Study of 370 tumour-free lymph nodes from 41 patients with squamous cell carcinoma in the head and neck region*

\begin{tabular}{lccc}
\hline & $\begin{array}{c}\text { Number of patients } \\
\text { without regional } \\
\text { lymph node }\end{array}$ & $\begin{array}{c}\text { Number of patients with regional lymph } \\
\text { node metastases }\end{array}$ \\
\cline { 3 - 4 } & $\begin{array}{c}\text { metastases (pN0)/ } \\
\text { number of tumour- } \\
\text { free lymph nodes }\end{array}$ & $\begin{array}{c}\text { (pN1)/number of } \\
\text { tumour-free lymph }\end{array}$ & $\begin{array}{c}(\mathrm{pN}>1) / \text { number of } \\
\text { tumour-free lymph } \\
\text { nodes }\end{array}$ \\
\hline Tumour sites & & & nodes \\
floor of mouth & $8 / 57$ & $2 / 39$ & $4 / 42$ \\
floor of mouth/tongue & $8 / 55$ & $1 / 1$ & $3 / 35$ \\
tongue & $3 / 10$ & $2 / 12$ & $1 / 13$ \\
buccal mucous membrane & $3 / 42$ & $1 / 22$ & - \\
ear & $1 / 11$ & $1 / 1$ & - \\
lip & $2 / 10$ & - & - \\
tonsil & - & $1 / 20$ & - \\
Grading & & & $3 / 40$ \\
pG1 & $4 / 37$ & - & $5 / 40$ \\
pG2 & $16 / 104$ & $3 / 35$ & - \\
pG3 & $5 / 44$ & $5 / 70$ & $5 / 58$ \\
Tumour spread & & & $2 / 16$ \\
T1 & $9 / 60$ & $1 / 11$ & $1 / 6$ \\
T2 & $9 / 67$ & $2 / 21$ & $8 / 80$ \\
T3 & $2 / 21$ & $2 / 33$ & - \\
T4 & $5 / 37$ & $3 / 40$ & \\
Total & $25 / 185$ & $8 / 105$ & - \\
\hline
\end{tabular}

${ }^{*}$ In another 5 lymph nodes from 4 of these 41 patients we detected immunohistochemically occult micrometastases with monoclonal antibodies CD44v6 und E48 and scored these separately from the immunohistochemically carcinoma-free lymph nodes: cf. 2.3.2 and Fig. 5.

Table 2

Study of lymphatic control tissues for comparison

\begin{tabular}{lc}
\hline Tissues examined & $\begin{array}{c}\text { Number of control } \\
\text { patients }\end{array}$ \\
\hline $\begin{array}{l}\text { Tuberculous lymph nodes with } \\
\text { epithelioid cell granulomas } \\
\text { Lymph nodes with non-specific }\end{array}$ & 10 \\
$\quad$ inflammation & 10 \\
Tonsils with tonsillitis & \\
Normal spleen & 6 \\
Spleen with perisplenitis & 2 \\
Total & 2 \\
\hline
\end{tabular}

\subsubsection{Immunohistochemical examination of} carcinoma cells in the micrometastases

We detected 5 lymph nodes from 4 patients with cells, which had formed as a micrometastasis (cf. footnote in Table 1). For the evaluation of the micrometastases, we confined the assessment to the carcinoma cells in them [26]. The expression of CD44v6 and E48 was scored by multiplying the staining intensity (SI) of the carcinoma cells by the percentage of positive carcinoma cells (PP) [65]. For comparison, the $5 \mathrm{mi}-$ crometastases and the 20 lymph node metastases of the same 41 patients [26] were immunohistochemically stained with a series of epithelial antibodies against cytokeratin and epithelial membrane antigens (cf. Table 3) and calculated exclusively as immunoreactive scores of the carcinoma cells [65], cf. [26,27].

\subsection{Statistical evaluation}

The immunohistochemical results of the CD44v6 $6^{+}$ and $\mathrm{E}_{4} 8^{+}$single cells in the tumour-free lymph nodes were calculated for their statistical significance with the $\chi^{2}$-test [66]. For the statistical comparison of expression in micrometastases and lymph node metastases, the $t$-test or the $U$-test by Mann and Whitney were used [66]. Calculations were made with the statistics program SigmaStat for Windows Version 1.0 (Jan- 
Table 3

Antibodies used to compare with the detected $\mathrm{CD} 44 \mathrm{v} 6^{+}$and/or E48 ${ }^{+}$cells in carcinoma-free lymph nodes (cf. Table 1) and to examine various lymphatic control tissues (cf. Table 2)

\begin{tabular}{|c|c|c|c|}
\hline $\begin{array}{l}\text { Antibodies/ } \\
\text { dilutions }\end{array}$ & Manufacturer & $\begin{array}{l}\text { Pretreatment of } \\
\text { paraffin sections }\end{array}$ & Detection of \\
\hline Ck MNF116/ & DAKO & \multirow[t]{2}{*}{ mw and proteinase $\mathrm{K}$} & \multirow[t]{2}{*}{ Ck-10, Ck-17, Ck-18 } \\
\hline $1: 25$ & M 0821 & & \\
\hline EMA/ & DAKO & \multirow[t]{2}{*}{$\mathrm{mw}$} & \multirow[t]{2}{*}{ epithelial membrane antigen } \\
\hline $1: 20$ & M 0613 & & \\
\hline Ber-EP4/ & DAKO & \multirow[t]{2}{*}{$\mathrm{mw}$ and proteinase $\mathrm{K}$} & \multirow[t]{2}{*}{ epithelial antigen } \\
\hline $1: 50$ & 0804 & & \\
\hline Ck-4 & BOEHRINGER & \multirow[t]{2}{*}{$\mathrm{mw}$} & \multirow[t]{2}{*}{ Ck-4 } \\
\hline $1: 50$ & 1273370 & & \\
\hline Ck-5/6 & BOEHRINGER & \multirow[t]{2}{*}{$\mathrm{mw}$ and proteinase $\mathrm{K}$} & \multirow[t]{2}{*}{ Ck-5, Ck-6 } \\
\hline $1: 10$ & 1273396 & & \\
\hline Ck-7 & DAKO & \multirow[t]{2}{*}{$\mathrm{mw}$ and proteinase $\mathrm{K}$} & \multirow[t]{2}{*}{ Ck-7 } \\
\hline $1: 100$ & M 7018 & & \\
\hline Ck-8 & PROGEN & \multirow[t]{2}{*}{$\mathrm{mw}$ and proteinase $\mathrm{K}$} & \multirow[t]{2}{*}{ Ck-8 } \\
\hline $1: 2000$ & 61031 & & \\
\hline Ck-17 & DAKO & \multirow[t]{2}{*}{$\mathrm{mw}$ and proteinase $\mathrm{K}$} & \multirow[t]{2}{*}{ Ck-17 } \\
\hline $1: 5$ & M 7046 & & \\
\hline Ck-18 & SIGMA & \multirow[t]{2}{*}{$\mathrm{mw}$} & \multirow[t]{2}{*}{ Ck-18 } \\
\hline $1: 400$ & C-1399 & & \\
\hline Ck-19 & DAKO & \multirow[t]{2}{*}{$\mathrm{mw}$ and proteinase $\mathrm{K}$} & \multirow[t]{2}{*}{ Ck-19 } \\
\hline $1: 20$ & M 0888 & & \\
\hline Ck-19 & DAKO & \multirow[t]{2}{*}{ mw and proteinase $\mathrm{K}$} & \multirow[t]{2}{*}{ Ck-19 } \\
\hline $1: 20$ & M 772 & & \\
\hline CD4 & DAKO & \multirow[t]{3}{*}{$\mathrm{mw}$} & \multirow[t]{3}{*}{$\mathrm{CD} 4+\mathrm{T}$ cells } \\
\hline (CD45RO) & MO834 & & \\
\hline $1: 500$ & & & \\
\hline CD8 & DAKO & \multirow[t]{2}{*}{$\mathrm{mw}$} & \multirow[t]{2}{*}{$\mathrm{CD}^{+}{ }^{+} \mathrm{T}$ cells } \\
\hline $1: 100$ & M7103 & & \\
\hline CD68 & DAKO & \multirow[t]{2}{*}{ mw and proteinase $\mathrm{K}$} & \multirow[t]{2}{*}{ monocytes and macrophages } \\
\hline $1: 2000$ & M 0814 & & \\
\hline
\end{tabular}

del Scientific, Erkrath, Germany). We correlated the occurrence of CD44v6 ${ }^{+}$and/or E48 ${ }^{+}$cells with the further course of the patients' disease in the KaplanMeier curve using the SPSS program for Microsoft Windows Version 6.1 (SPSS Inc., Chicago, USA).

\section{Results}

3.1. Detection of $C D 44 v 6^{+}$and/or E48 ${ }^{+}$single cells in carcinoma-free lymph nodes in patients with a squamous cell carcinoma of the head and neck region

Of the 370 tumour-free lymph nodes from the 41 patients with a head neck tumour (cf. Table 1 and
Fig. 1), we demonstrated positively immunostained single cells in 211 lymph nodes. CD44v6 ${ }^{+}$single cells were found in 205 lymph nodes, and $\mathrm{E} 48^{+}$single cells in 41 lymph nodes: Table 4, Fig. 1 (cf. 2.3.1). In 34 of the 205 lymph nodes with CD44v6 ${ }^{+}$cells we also found $\mathrm{E} 48^{+}$cells. In 6 lymph nodes with $\mathrm{E} 48^{+}$cells, no CD44v6 ${ }^{+}$cells were present. The number of lymph nodes with stained cells was higher for both markers in patients with a lymph node metastasis than in $\mathrm{pN} 0$ patients. However, CD44v6 $6^{+}$cells were demonstrated most frequently in patients with $\mathrm{pN} 1(\mathrm{pN} 1: \mathrm{pN}>1=$ $70 \%: 51 \% ; p=0.01) . \mathrm{E}^{2} 8^{+}$cells were detected most frequently in $\mathrm{pN}>1$ patients $(\mathrm{pN}<1: \mathrm{pN}>1=$ $6 \%: 29 \% ; p<0.001)$. 


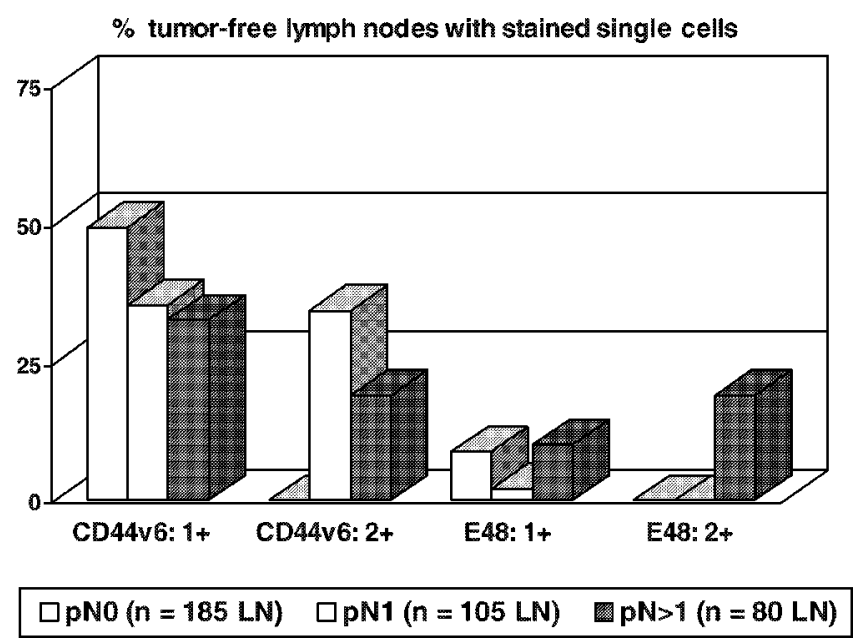

Fig. 1. Results of the examination of 370 tumour-free lymph nodes (LN) in patients with squamous cell carcinoma in the head-neck region. CD $44 \mathrm{v6}^{+}$single cells were present in 205 lymph nodes and E48 ${ }^{+}$single cells in 41 lymph nodes. Altogether, we found stained single cells in 211 lymph nodes (cf. Table 4). In most of the lymph nodes we found solitary to scattered distribution of stained single cells (rated with $1+$ ). Abundant to massive numbers (rated with $2+$ ) of $\mathrm{CD}_{4} 4 \mathrm{v} 6^{+}$single cells were not present in lymph nodes from pN0 patients and abundant to massive numbers of $\mathrm{E}^{+} 8^{+}$single cells were found solely in lymph nodes from $\mathrm{pN}>1$ patients.

\section{Table 4}

Evidence of positively stained single cells in 370 carcinoma-free lymph nodes in 41 patients with squamous cell carcinoma in the head and neck region

\begin{tabular}{lcc}
\hline & CD44 v6 & E48 \\
\hline Lymph nodes with stained single cells/ & & \\
total number of lymph nodes & $205 / 370$ & $41 / 370$ \\
pN0 patients & $91 / 185$ & $16 / 185$ \\
pN $>0$ patients & $114 / 185$ & $25 / 185$ \\
pN1 patients & $73 / 105$ & $2 / 105$ \\
pN $>1$ patients & $41 / 80$ & $23 / 80$ \\
& & \\
Number of stained cells in the lymph & & \\
nodes ${ }^{1}$ : & & \\
& & \\
Solitary to scattered distribution of & & \\
stained cells (1+): & $154 / 205$ & $26 / 41$ \\
pN0 patients & $91 / 185$ & $16 / 185$ \\
pN $>0$ patients: & $63 / 185$ & $10 / 185$ \\
pN1 patients & $37 / 105$ & $2 / 105$ \\
pN $>1$ patients & $26 / 80$ & $8 / 80$ \\
Abundant to massive stained cells $(2+):$ & $51 / 205$ & $15 / 41$ \\
pN0 patients & $0 / 185$ & $0 / 185$ \\
pN $>0$ patients: & $51 / 185$ & $15 / 185$ \\
pN1 patients & $36 / 105$ & $0 / 105$ \\
pN $>1$ patients & $15 / 80$ & $15 / 80$ \\
\hline
\end{tabular}

${ }^{1}$ Evaluation of the lymph nodes, cf. 2.3.1.

In the carcinoma-free lymph nodes, the number of $\mathrm{CD} 44 \mathrm{v6}^{+}$cells was significantly higher than that of $\mathrm{E}_{4} 8^{+}$cells: $55 \%$ and $11 \%(p<0.001)$, re- spectively. Table 4 and Fig. 1 clearly show that we found immunostained single cells in carcinoma-free lymph nodes from pN0 patients less frequently than in carcinoma-free lymph nodes from $\mathrm{pN}>0$ patients. However the difference is significant only with CD44v6 for $\mathrm{pN} 0: \mathrm{pN}>0=49 \%: 62 \%(p=0.025)$; by contrast for $\mathrm{E} 48=9 \%: 14 \%(p>0.05)$. The number of stained single cells in the lymph nodes increased significantly with both markers from $\mathrm{pN} 0$ to $\mathrm{pN}>1$ patients $(p<$ $0.001)$. In none of the $\mathrm{pN} 0$ patients did we detect abundant to massive stained single cells (evaluation 2+; cf. 2.3.1). Notably, abundant to massive presence of CD44v6 ${ }^{+}$cells was demonstrated in lymph nodes from $\mathrm{pN} 1$ patients more frequently than in $\mathrm{pN}>1$ patients (34\% : 19\%). By contrast, we found abundant to massive numbers of $\mathrm{E} 48^{+}$cells only in $\mathrm{pN}>1$ patients (19\%). All of the CD44v6 ${ }^{+}$and/or E48 ${ }^{+}$cells thus evaluated were single cells, as opposed to cells separately specified positive, which were to be found in small cell clusters and were identified histopathologically as micrometastases (cf. 2.3.2 and 3.5).

\subsection{Examination of the $\mathrm{CD} 44 \mathrm{v} 6^{+}$and $\mathrm{E} 48^{+}$cells with various epithelial antibodies as a control procedure}

Altogether, 211 carcinoma-free lymph nodes contained CD44v6 ${ }^{+}$and/or E48 ${ }^{+}$single cells (cf. Table 4 and Fig. 1). We examined these lymph nodes immunohistochemically with the antibodies against epithelial 


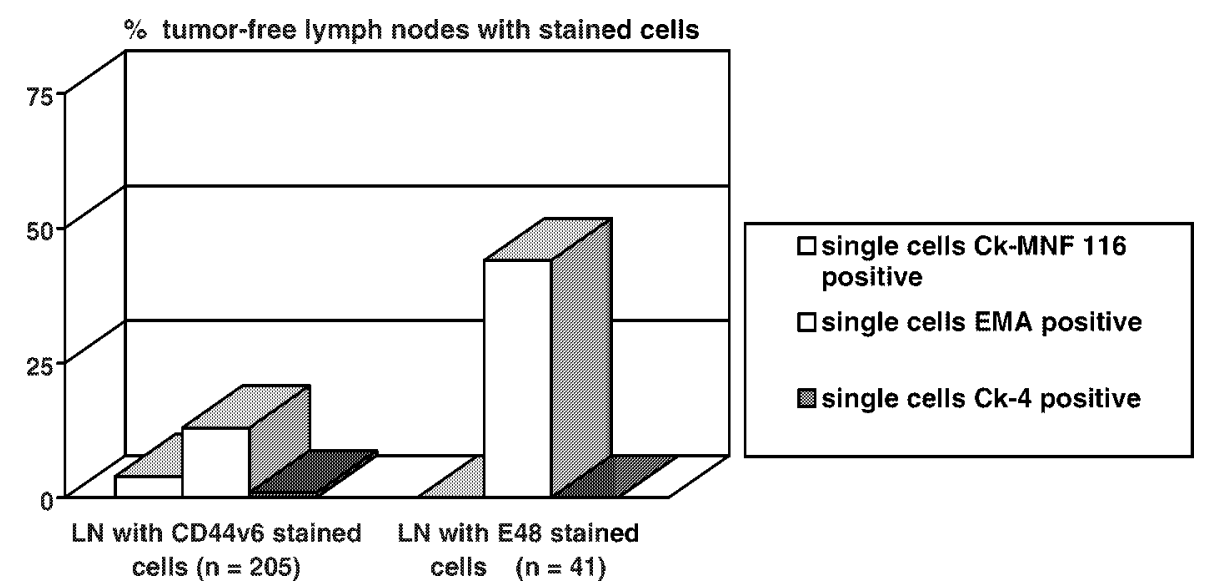

Fig. 2. Results of the 205 tumour-free lymph nodes (LN) with stained CD44v6 single cells and 41 tumour-free lymph nodes with positive E48 single cells (altogether 211 lymph nodes with stained single cells) examined by various antibodies against epithelial markers (cytokeratin and membrane markers, cf. Table 3). With epithelial markers stained single cells were found only in a few lymph nodes, with the exception of EMA ${ }^{+}$ single cells in $44 \%$ of tumour-free lymph nodes with $\mathrm{E}^{+} 8^{+}$cells. No stained cells were demonstrated in any of the other epithelial antibodies (Table 3).

markers (cytokeratin and membrane markers listed in Table 3) using APAAP and evaluated the stained single cells using the same method as with CD44v6 ${ }^{+}$and E48 ${ }^{+}$, cf. 2.3.1. Figure 2 shows that cells immunostained with epithelial markers were demonstrated only in a few lymph nodes with Ck-MNF 116, EMA, and Ck-4, and these were usually only solitary, positively stained single cells. Only in one pN1 patient did we demonstrate along with many CD44v6 ${ }^{+}$cells an abundance of stained EMA-cells. The E48 immunostain was negative in the lymph nodes of this patient. Neither in terms of location or morphology were the EMA cells identical to the CD44v6 ${ }^{+}$cells. By comparison, $44 \%$ of tumour-free lymph nodes with $\mathrm{E} 48^{+}$ cells had $\mathrm{EMA}^{+}$cells located in a similar position. All other epithelial antibodies (Table 3) were nonreactive.

\subsection{Examination of the lymphatic control tissues with the monoclonal antibodies CD44v6, E48 and all control antibodies (Table 3)}

To elucidate the origin of the CD44v6 ${ }^{+}$and E48 ${ }^{+}$ cells, we examined 30 control tissue specimens (cf. Table 2). In the spleens and tonsils examined we found neither CD44v6 ${ }^{+}$nor E48 ${ }^{+}$cells. We did however find CD44v6 ${ }^{+}$cells in the tuberculous lymph nodes as well as in non-specifically inflamed lymph nodes. The proportion of positively stained cells in these lymphatic tissues was significantly higher than in the 370 tumourfree lymph nodes. It attained the highest proportion in the tuberculous lymph nodes, in particular in epithelioid cell granulomas of these lymph nodes. $80 \%$ of the lymph nodes with non-specific lymphadenitis contained CD44v6 ${ }^{+}$cells, albeit in smaller numbers than in the tuberculous lymph nodes. The CD44v6 ${ }^{+}$cells in tuberculous lymph nodes were compared with the immunohistochemical reaction of the diverse antibodies (cf. Table 3): Fig. 3. All multinuclear Langhans giant cells were $\mathrm{CD} 44 \mathrm{v} 6^{+}$but were negative with all epithelial markers. The reaction of the monoclonal antibody CD44v6 ${ }^{+}$in the tuberculous lymph nodes, in particular in epithelioid cell granulomas, was partially comparable to the reaction of cells stained by the monoclonal antibody CD4. Unlike CD8 ${ }^{+}$cells, which prefer to settle in the outer boundary of the epithelioid cell granuloma, $\mathrm{CD}^{+}{ }^{+}$and $\mathrm{CD} 44 \mathrm{v} 6^{+}$cells prefer the inner boundary of the granulomas. Outside the granuloma and in other regions of the lymph nodes, we did however demonstrate, as a rule, more $\mathrm{CD}^{+}{ }^{+}$cells than the significantly smaller number of $\mathrm{CD}_{4} 4 \mathrm{v} 6^{+}$cells. Moreover, the multinuclear Langhans giant cells were CD44v6 ${ }^{+}$, while there was no staining by CD4. In contrast to $\mathrm{CD} 44 \mathrm{v} 6^{+}$and $\mathrm{CD}^{+}{ }^{+}$cells, $\mathrm{CD} 8^{+}$cells were settled predominantly in the centre of epithelioid cell granulomas in the tuberculous lymph nodes. Abundant to massive numbers of $\mathrm{CD} 68^{+}$cells (monocytes and macrophages) were distributed over the entire lymph node, including the epithelioid cell granuloma, and were present in greater numbers than were CD44v6 ${ }^{+}$ cells.

$\mathrm{E} 48^{+}$cells were detected neither in the inflamed lymph nodes, nor in the epithelioid cell granulomas of 


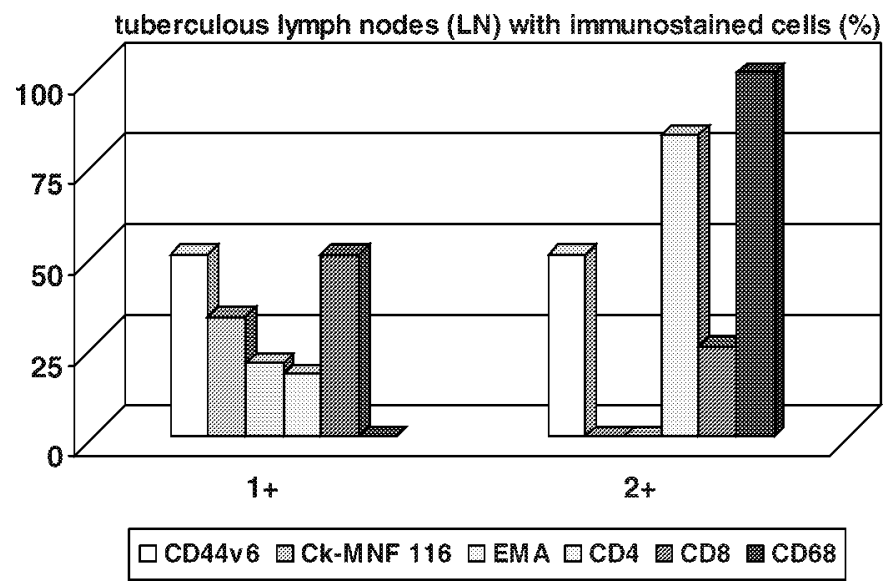

Fig. 3. Immunohistochemical comparison of CD44v6 in tuberculous control lymph nodes with the expression of other markers (Table 3). In non-specifically inflamed lymph nodes (cf. Table 2) - not mentioned here - we found smaller numbers of stained cells than in tuberculous lymph nodes. The reaction in tuberculous lymph nodes and non-specifically inflamed lymph nodes was negative with other antibodies and with E48 also not mentioned here. In the normal spleens, in spleens with perisplenitis and in the tonsils with tonsillitis no positively stained single cells were demonstrated.

Table 5

Postoperative course of disease in the 41 patients participating in the study with squamous cell carcinoma of the head and neck region (cf. Fig. 4)

\begin{tabular}{lcc}
\hline & $\begin{array}{c}\text { Number of patients } \\
\text { with relapse* }^{*}\end{array}$ & $\begin{array}{c}\text { Number of patients } \\
\text { without relapse }\end{array}$ \\
\hline Patients with lymph nodes containing CD44v6 ${ }^{+}$single cells (cf. 2.3.1): & 15 & 14 \\
lymph nodes with solitary to scattered distribution of CD44v6 ${ }^{+}$cells (1+) & 12 & 11 \\
lymph nodes with abundant to massive CD44v6 ${ }^{+}$cells (2+) & 3 & 3 \\
Patients with lymph nodes lacking CD44v6 ${ }^{+}$cells: & 7 & 5 \\
Patients with lymph nodes containing E48 ${ }^{+}$single cells (cf. 2.3.1): & 7 & 3 \\
lymph nodes with solitary to scattered distribution of E48 $8^{+}$cells (1+) & 5 & 2 \\
lymph nodes with abundant to massive E48 ${ }^{+}$cells (2+) & 2 & 1 \\
Patients with lymph nodes lacking E48 ${ }^{+}$cells: & 15 & 16 \\
\hline
\end{tabular}

${ }^{*}$ Relapse, secondary tumour, metastasis or death.

the tuberculous lymph nodes, nor in the lymph node areas outside the granulomas.

\subsection{Possible role of $C D 44 v 6^{+}$and E48 $8^{+}$cells for the further course of tumour disease}

Follow-up data on the 41 cancer patients in this study up to the first appearance of relapse (recurrence, secondary tumour, metastasis or death) is recorded in Table 5. This was compared to the demonstration of CD44v6 ${ }^{+} / \mathrm{CD} 44 \mathrm{v} 6^{-}$cells (Fig. $4 a$ ) and $\mathrm{E} 48^{+} / \mathrm{E} 48^{-}$ cells (Fig. 4b) in the carcinoma-free lymph nodes using the Kaplan-Meier curve. Patients with CD44v6 ${ }^{+}$ cells in the lymph nodes suffered relapse with a distinct but still statistically insignificant delay compared to patients without $\mathrm{CD} 44 \mathrm{v} 6^{+}$cells in the lymph nodes
(20 months as opposed to 11 months $(p>0.05)$ ). The onset of relapse did not significantly differ between patients with ${\mathrm{E} 48^{+}}^{+}$single cells in the lymph nodes (20 months) and those without $\mathrm{E} 48^{+}$cells (17 months): $p>0.1$.

\subsection{Detection of occult micrometastases}

Using the monoclonal antibodies against CD44v6 and E48 we detected small occult micrometastases in 5 lymph nodes from 4 patients (10\% of the patients) among the original total of 375 lymph nodes (1\%). These 5 lymph nodes were carcinoma-free in routine histopathology using the hematoxylin-eosin staining. In the micrometastases, only the carcinoma cells were evaluated in the same manner as were the primary 


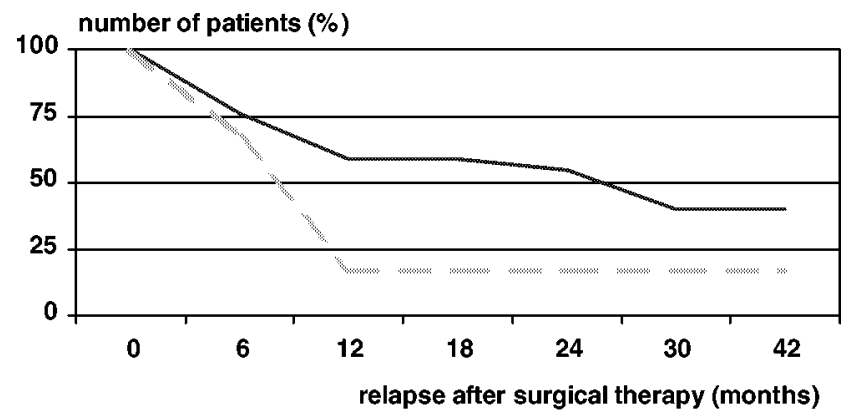

\begin{tabular}{|l|}
\hline patients with CD44v6-positive cells in lymph nodes $(n=29)$ \\
patients without CD44v6-positive cells in lymph nodes $(n=12)$
\end{tabular}

(a)

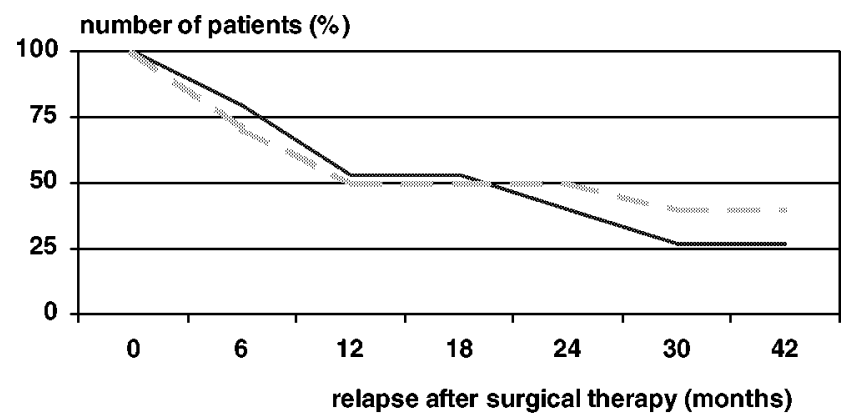

- patients with E48-positive cells inlymph nodes $(n=10)$

patients without E48-positive cells in lymph nodes $(n=31)$

(b)

Fig. 4. Postoperative course of disease in patients with squamous cell carcinoma in the head and neck region using the Kaplan-Meier curves: (a) Comparison of patients with CD44v6 ${ }^{+}$and of patients without CD44v6 ${ }^{+}$cells in tumour-free lymph nodes. The onset of relapse was not significantly later in patients with positive cells $(p>0.05)$. (b) Comparison of patients with E48 ${ }^{+}$and of patients without E48 ${ }^{+}$cells in tumour-free lymph nodes. The onset of relapse was not significantly later in patients without positive cells $(p>0.1)$.

tumours or lymph node metastases [26,27]. We estimated the immunoreactive cancer cell scores of the 5 micrometastases (cf. 2.3.2 [65]), both for CD44v6 and E48 and for the epithelial antibodies (cf. Table 3) and compared these results with the immunoreactive scores for the 20 lymph node metastases presented in Fig. 5. The immunoreactive scores of the carcinoma cells with the markers CD44v6 and E48, particularly with CD44v6, were generally higher than the epithelial antibody scores for cytokeratin and membrane markers. This was the case both with the percentage of positively stained carcinoma cells and with the immunostaining intensity.

Regarding the micrometastases, the mean immunoreactive score for CD44v6 was significantly higher than that for $\mathrm{E} 48(p=0.01)$ and for all epithelial markers $(p<0.001)$. In the same manner, in the 20 lymph node metastases the CD44v6 scores diverged statistically from the E48 scores $(p<0.01)$ and from the scores of all other epithelial markers (cytokeratin MNF116, epithelial membrane antigen (EMA): $p<0.025$; all other markers: $p<0.01$ ). By contrast, the scores of the epithelial markers and of E48 were not statistically different, either for the 5 micrometastases $(p>0.1)$ or for the 20 lymph node metastases $(p>0.05)$.

\section{Discussion}

Fifty percent of all patients with head-neck tumours suffer recurrence or secondary tumour [54]. This could be attributable to the fact that malignant molecular changes in the resection margins escape histopatholog- 


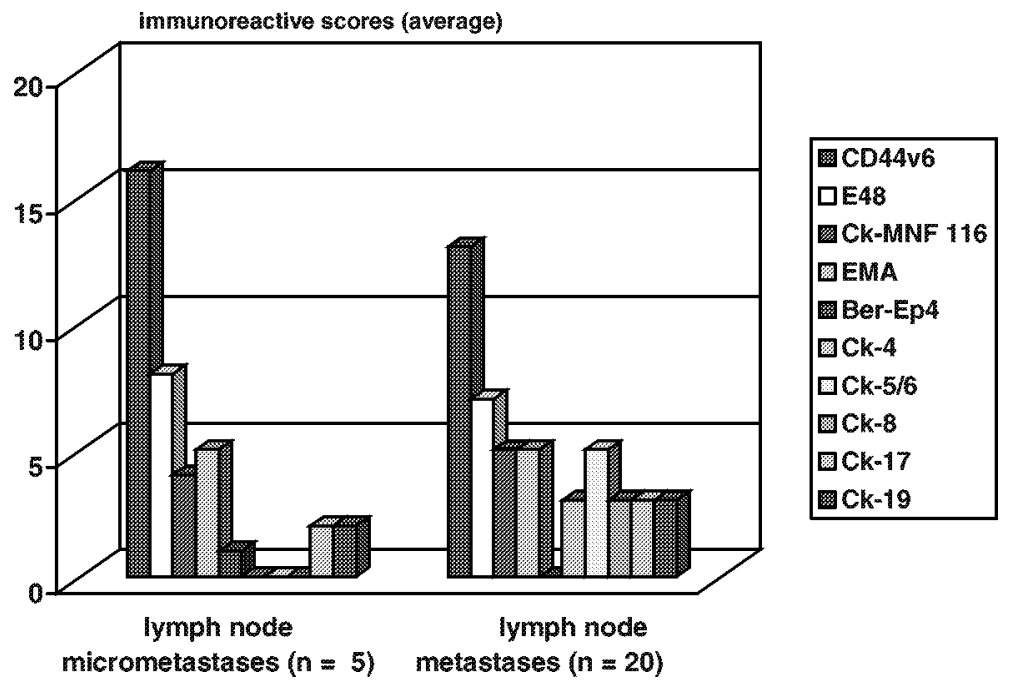

Fig. 5. Immunoreactive cancer cell scores (cf. 2.3.2) of the expression of CD44v6 and E48 in 5 lymph node micrometastases and in 20 overt lymph node metastases, compared with epithelial markers (cf. Table 3). The reactions with other epithelial antibodies not mentioned here were negative in this examination.

ical detection and are thus "overlooked". The further course of disease could also be determined by disseminated carcinoma cells not detected in histopathology, for example in lymph nodes.

Only with the immunohistochemical and molecularbiological characterization both of the invasive tumour fronts and of the tumour-free margins did it become possible to elaborate new prognostic criteria for squamous cell carcinoma of the head and neck to supplement histopathology. Primarily the parameters of proliferative activity and apoptosis are evaluated [1317,44,56,58-60]. Even subclinical molecular changes should be given adjuvant therapy [39].

Clinical observations and model investigations have shown that with the development of a primary tumour its metastatic spread has already begun $[19,28,29,41$, $43,69,73]$, and since the end of the 1980's the dissemination of epithelial cells in mesenchymal surroundings (bone marrow, lymph nodes or blood) has been investigated [11,12,24,30], cf. [21,51-53,61]. Since disseminated carcinoma cells are mostly found outside the cell cycle in the $G_{0}$ phase $[23,51,53]$, they elude both the postoperative radiotherapy and chemotherapy of headneck tumour patients. These cells might however be of significance for the further course of disease. This failure to catch the $G_{0}$ carcinoma cells at this early stage could be a reason why head-neck tumours show a high rate of recurrence or secondary carcinomas.

With the aim of finding an adjuvant active immunotherapy, the expression of the tumour-associated adhesion molecules CD44v6 and E48 was investigated in the histopathologically tumour free lymph nodes of patients with a squamous cell carcinoma of the head and neck region. Our efforts, in concurrence with those of other authors [34,48,70,72], cf. [47], were directed towards the postoperative elimination of dormant carcinoma cells with a target-associated adjuvant cytotoxic immunotherapy. In a former head-neck tumour study we characterized 60 tumours and 20 lymph node metastases of patients with a squamous cell carcinoma in this region [26,27]. These examinations yielded results concurrent with other authors $[35,36,57,63,67$, 68] - the markers CD44v6 and E48 appear on all primary tumours and lymph node metastases of headneck tumour patients. However, like Hyckel et al. [36] and Salmi et al. [67], we encountered different parts of positive carcinoma cells and the colour intensity on the cells, depending on the tumour grade, and obtained different immunoreactive scores cf. [65] for the tumours and metastases. Poorly differentiated tumours showed a downregulation of both epitopes. With the monoclonal antibody CD44v6 we obtained significantly higher scores for squamous cell carcinoma of the head-neck region than with the monoclonal antibody E48.

In this study we investigated whether cells of different histogenesis carry the epitope CD44v6 and/or E48 in tumour-free lymph nodes. By comparison with different antibodies and by examination of various lymphatic tissues we attempted to classify the stained cells. The successful classification of the stained cells is crucial for establishing the best peptide for a spe- 
cific adjuvant immunotherapy and for finding disseminated carcinoma cells in extirpated histophathologically tumour-free lymph nodes with RT-PCR. Prior to an adjuvant immunotherapy, we are planning to screen suitable patients for this therapy with a molecular biologic examination of tumour-free lymph nodes from the patient using a CD44v6- and/or E48-specific RT-PCR.

\subsection{Significance of $C D 44 v 6^{+}$single cells in carcinoma-free lymph nodes of patients with head-neck tumour}

In 205 of the 370 tumour-free lymph nodes (55\%) we discovered isolated to massive numbers of CD44v6 ${ }^{+}$single cells: Table 4 and Fig. 1 . It is conceivable that the more frequent evidence of CD44v6 ${ }^{+}$ cells and the increased number of CD44v6 ${ }^{+}$single cells in tumour-free lymph nodes compared to $\mathrm{E} 48^{+}$ single cells in the same tumour-free lymph nodes $(9 \%$; cf. 4.2) is related to the stronger expression of the epitope CD44v6 found both in the primary tumour and lymph node metastasis of the same patient [26,27].

We included the expression of different other markers in this study (cf. Table 3 ) to help clarify the question of whether all the cells which stained positive are of epithelial origin, particularly since CD44v6 is also present on various hematopoietic cells $[4,42]$. Since the CD44v6 ${ }^{+}$cells in the carcinoma-free lymph nodes are non-contiguous single cells in a scattered to crowding distribution, it can be excluded that they could be micrometastases. Although labeling with epithelial antibody (Table 3) did not show detectable staining of the same cells by CD44v6 in carcinoma-free lymph nodes, it cannot be ruled out that some few of the CD44v6 ${ }^{+}$ cells are epithelial (cf. Fig. 2), even if we cannot definitively prove this for certain with our epithelial markers. Positively stained single cells in these lymph nodes could have escaped observation, as they were very few in number and stained only minimally with the less sensitive epithelial markers. This low sensitivity of the epithelial markers was observed in our investigation of micrometastases and lymph node metastases (Fig. 5).

In patients with lymph node metastasis, the number of carcinoma-free lymph nodes with CD44v6 $6^{+}$cells and the number of CD44v6 $6^{+}$cells in the carcinomafree lymph nodes increased compared to the findings in pN0 patients (Fig. 1 and Table 4). Contrary to E48 (cf. 4.2), there were not significantly more CD44v6 ${ }^{+}$cells in lymph nodes of $\mathrm{pN}>1$ patients than in $\mathrm{pN} 1$ patients. We also found lymph nodes with abundant numbers of
$\mathrm{CD} 44 \mathrm{v} 6^{+}$cells more frequently in $\mathrm{pN} 1$ patients than in $\mathrm{pN}>1$ patients $(49 \%: 37 \%)$. This may indicate some form of a reduced local immunoreaction to advanced tumour growth.

Another objection that might be raised is that the CD44v6 $6^{+}$cells as demonstrated in tumour-free lymph nodes were not as a rule epithelial cells. In the tuberculous lymph nodes we found abundant individual CD44v6 ${ }^{+}$cells in the epitheloid cell granulomas (Fig. 3). The location of the CD44v6 ${ }^{+}$cells in the epithelioid cell granulomas corresponded virtually to that of $\mathrm{CD}^{+}$cells. Both were settled primarily near the inner boundary of the epithelioid cell granulomas cf. [40]. In the tuberculous lymph node, where they stained with equal intensity, we found far more $\mathrm{CD}^{+}$than $\mathrm{CD} 44 \mathrm{v} 6^{+}$cells outside the granuloma. While the monoclonal antibody CD45RO which we used predominantly marks activated lymphocytes, it also marks naive lymphocytes. Notably, fewer than $1 \%$ of naive lymphocytes in lymph nodes express CD44v6 [75], cf. [50]. This fact, along with the somewhat reduced number of $\mathrm{CD} 44 \mathrm{v} 6^{+}$cells in comparison to $\mathrm{CD}^{+}{ }^{+}$cells, leads to the tentative conclusion that cells which express both CD4 and CD44v6 are activated T-lymphocytes. Arch et al. [4], cf. [42] were able to inhibit activated T-lymphocytes with anti-CD44v6antibodies, cf. [46]. According to the findings by Wittig et al. [74,75], CD44v6 ${ }^{+}$lymphocytes are TH1 cells. Their essential role for cell-mediated immunity is known [1], cf. [47,75].

It is important to note the diverse settlement of $\mathrm{CD}^{+}$cells in the granulomas in and outside the outer boundary and also throughout the entire tuberculous lymph node at sites not settled by the CD44v6 ${ }^{+}$cells. Similarly, the comparison with the staining of the macrophage-monocyte marker CD68 revealed, as anticipated, that the number and distribution of $\mathrm{CD}^{+}{ }^{+}$ cells were only partially identical with that of the CD44v6 ${ }^{+}$cells. CD68 ${ }^{+}$cells were distributed in abundance entirely throughout all of the tuberculous lymph nodes. Finally, we demonstrated CD44v6 ${ }^{+}$cells in non-specifically inflamed lymph nodes as well, albeit in smaller quantities than in the tuberculous lymph nodes.

We believe that the CD44v6 ${ }^{+}$single cells in carcinoma-free lymph nodes signal a basic activation of the local immunodefenses, similar to a milder or stronger cell-mediated defense. According to Wittig et al. [74, 75], cf. [46], CD44v6 ${ }^{+}$cells point to a synergetic process of activated T-helper cells and macrophages as a sort of delayed type of immunoreaction. This might ex- 
plain the further course of disease (Fig. 4a and Table 5). Patients with CD44v6 ${ }^{+}$cells had fewer relapses and relapsed later than did patients without $\mathrm{CD} 44 \mathrm{v} 6^{+}$cells. In order to confirm the presence of CD44v6 ${ }^{+}$cells in tumour-free lymph nodes as an available marker for local immune response to the tumour we want to proceed with our study on a larger group of head and neck tumour patients. The application of the CD44v6-peptide does not appear to be acceptable for the development of postoperative active immunotherapy. However, van Hal et al. [34] have introduced the monoclonal antiU36 antibody - which is largely identical to CD44v6 - as a suitable candidate for passive immunotherapy. It is conceivable that success or failure of active immunotherapy in eliminating disseminated tumour cells or in interfering with the cell-mediated immune response to the tumour might in the end trigger the phenomenon of immunological enhancement of tumour growth.

\subsection{Significance of the $\mathrm{E}^{+} 8^{+}$cells in carcinoma-free lymph nodes of patients with head-neck cancer}

In 34 out of the 370 tumour-free lymph nodes (9\%) we detected $\mathrm{E} 48^{+}$single cells: Table 4 and Fig. 1. E48 has been demonstrated to date only on keratinocytes, transitional epithelia and on squamous cells and/or on their malignant counterparts $[6,63,68]$. This is corroborated by the fact that we found $\mathrm{E} 48^{+}$cells in contrast to CD44v6 neither in tuberculous epithelioid cell granulomas nor in non-specifically inflamed lymph nodes. In the carcinoma-free lymph nodes the number of lymph nodes with $\mathrm{E}_{4} 8^{+}$single cells rose markedly from $\mathrm{pN} 0$ to $\mathrm{pN}>1$ patients and only in $\mathrm{pN}>1$ patients with advanced disease did we find abundant $\mathrm{E} 48^{+}$cells. On the basis of our findings we would suggest that the E48 ${ }^{+}$single cells may be disseminated tumour cells which have not yet formed into a micrometastasis.

In the 34 tumour-free lymph nodes with $\mathrm{E} 48^{+}$single cells we were unable to demonstrate with the epithelial antibodies (cf. Table 3 ) that the $\mathrm{E}^{+} 8^{+}$single cells were epithelial cells. Only with the antibodies against the epithelial membrane antigen (EMA, cf. Table 3 ) could we detect in $44 \%$ of the same tumour-free lymph nodes $\mathrm{EMA}^{+}$single cells in comparable location and with comparable morphology. The other epithelial markers were negative (Fig. 3). We know, on the one hand, however, that EMA not only marks epithelial cells but is also expressed on normal lymph-cells [5,18,22,45]. And on the other hand, the comparison of the immunohistochemical demonstration of epithelial mark- ers on the 20 lymph node metastases with E48 revealed that the immunohistochemical scores of the epithelial marker in the paraffin sections are lower than those for E48 (cf. Fig. 5). Evidence of single cells positive with epithelial markers was rarer in the 34 tumourfree lymph nodes with $\mathrm{E}^{4} 8^{+}$single cells. This could be attributable to the lower sensitivity of the epithelial markers. Nonetheless by way of analogy we would draw a cautious conclusion from our findings that the $\mathrm{E} 48^{+}$single cells in the tumour-free lymph nodes are most likely epithelial cells as are possibly disseminated carcinoma cells.

Regarding the further course of disease in patients with $\mathrm{E} 48^{+}$single cells (Fig. $4 \mathrm{~b}$ and Table 5), the Kaplan-Meier curve is very similar to that of patients without $\mathrm{E} 8^{+}$cells. Relapse became evident in $70 \%$ of the patients with E48 ${ }^{+}$cells and only in $48 \%$ of the patients without these cells (no significance: $p>0.1$ ). There was no evidence that recurrence was more frequent in patients with demonstrated E48 single cells, or that these cells influenced the further course of disease. Given that only 41 cancer patients were involved in our study, this observation must be verified with a larger patient population.

\subsection{Detection of micrometastases in lymph nodes from patients with head neck cancer by the monoclonal antibodies CD44v6 and E48}

It is well known that in routine histopathology the chances of detecting a micrometastasis of 3 cell diameter in one section of the hematoxylin and eosin (HE) staining is $1: 100$ [33]. As a rule, in routine histopathology only one section of each extirpated lymph node is evaluated. We evaluated three sections per lymph node with our two markers CD44v6 and E48 and were able to detect 5 micrometastases from 4 patients from among the 375 lymph nodes originally judged to be tumour-free (cf. Table 1). The perceptable staining intensity of both markers in immunohistochemistry confirmed this discovery. We were able to ascertain that with both monoclonal antibodies CD44v6 and E48 micrometastases could be well marked immunohistochemically, somewhat better with CD44v6 than the 20 lymph node metastases (Fig. 5). We used both the 5 micrometastases and the 20 lymph node metastases to evaluate our findings from the tumour-free lymph nodes in order to determine the immunoreactive sensitivity of several epithelial markers in paraffin sections (cf. Table 3). The immunoreactive score was significantly higher in the mi- 
crometastases with CD44v6 than with E48 ( $p=0.01)$. This was less pronounced in the 20 lymph node metastases $(p<0.025)$. Figure 5 shows that micrometastases and lymph node metastases cannot be demonstrated as well with the epithelial markers used as with CD44v6 and E48 $(p<0.001)$. We deduce from this that the reduced sensitivity of the epithelial markers also pertains to the immunohistochemical proof of disseminated single cells.

It is evident that the further course of disease can be determined by a very few disseminated carcinoma cells [49]. Highly sensitive markers are therefore being sought to recognize micrometastases and to eliminate them therapeutically $[2,3,11,12,21,24,38,49,71]$. Nevertheless, the interpretation and significance of individual cells which have been demonstrated to be occult metastases remains controversial [11,21,33,37]. A sufficiently extended postoperative observation period and an adequate number of patients are necessary to be able to evaluate the findings.

\subsection{Conclusions}

Our findings in carcinoma-free lymph nodes from patients with squamous cell carcinoma of the head and neck region emphasize that for a postoperative immunotherapy a peptide sequence of E48 seems more appropriate than CD44v6 despite better immunohistochemical characterization by CD44v6 of squamous cell carcinomas of the head and neck region and of lymph node metastases [26,27]. It remains to be seen to what extent a E48-specific RT-PCR with a substantially higher sensitivity would prove superior in finding of disseminated carcinoma single cells [7,24]. To screen for suitable patients for the postoperative immunotherapy with a E48-peptide vaccine, we envisage continuing our histopathologic examination of lymph nodes without metastasis using a E48-specific RT-PCR.

\section{Acknowledgements}

This work was supported by the European Science Foundation (ESF).

We are indebted to Prof. Warnaar, Vice President of Cancer Research, CENTOCOR B.V. (Leiden, The Netherlands) for the generous gift of the monoclonal antibody E48 used in this study.

We thank Prof. Dr. G.-P. Wildner, Robert-RössleClinic, Berlin and Prof. Dr. H. Lobeck, Institute of
Pathology, "Ernst von Bergmann" Clinic, Potsdam, for critical evaluation of a number of histologic sections and for helpful discussion of results as well as Dr. W. Schmidt's statistical evaluation (Max Delbrueck Center, Berlin). The skilled immunohistochemical techniques were carried out by Mrs. U. KruseBoitschenko and we also acknowledge Mrs. C. Aubel's secretarial support.

\section{References}

[1] A.K. Abbas, K.M. Murphy and A. Sher, Functional diversity of helper T lymphocytes, Nature 383 (1996), 787-793.

[2] P. Ambrosch and U. Brinck, Detection of nodal micrometastases in head and neck cancer by serial sectioning and immunostaining, Oncology Huntingt. 10 (1996), 1221-1229.

[3] P. Ambrosch, M. Kron, G. Fischer and U. Brinck, Micrometastases in carcinoma of the upper aerodigestive tract: detection, risk of metastasizing, and prognostic value of depth of invasion, Head and Neck 17 (1995), 473-479.

[4] R. Arch, K. Wirth, M. Hofmann, H. Pota, S. Matzku, P. Herrlich and M. Zöller, Participation in normal immune response of a metastasis-inducing splice variant of CD44, Science 257 (1992), 682-685.

[5] R. Beschoner, H.P. Horny, U.R. Petrusch and E. Kaiserling, Frequent expression of haemopoietic and non-haemopoietic antigens by reactive plasma cells: an immunohistochemical study using formalin-fixed, paraffin-embedded tissue, Histol. Histopathol. 14 (1999), 805-812.

[6] R.H. Brakenhoff, M. Gerretsen, E.M.C. Knippels, M. van Dijk, H. van Essen, D.O. Weghuis, R.J. Sinke, G.B. Snow and G.A.M.S. van Dongen, The human E48 antigen, highly homologous to the murine Ly- 6 antigen ThB, is a GPI-anchored molecule apparently involved in keratinocyte cell-cell adhesion, J. Cell Biol. 129 (1995), 1677-1689.

[7] R.H. Brakenhoff, J.G. Stroomer, C. ten Brink, R. de Bree, S.M. Weima, G.B. Snow and G.A.M.S van Dongen, Sensitive detection of squamous cells in bone marrow and blood of head and neck cancer patients by E48 reverse transcriptasepolymerase chain reaction, Clin. Cancer Res. 5 (1999), 725733.

[8] R. de Bree, J.C. Roos, J.J. Quak, W. den Hollander, M.W. van den Brekel, J.E. van der Wal, H. Tobi, G.B. Snow and G.A. van Dongen, Clinical imaging of head and neck cancer with technetium-99m-labeled monoclonal antibody E48 IgG or $\mathrm{F}\left(\mathrm{ab}^{\prime}\right) 2$, J. Nucl. Med. 35 (1994), 775-783.

[9] R. de Bree, J.C. Ross, J.J. Quak, W. den Hollander, G.B. Snow and G.A.M.S. van Dongen, Radioimmunoscintigraphy and biodistribution of technetium-99m-labeled monoclonal antibody U36 in patient with head and neck cancer, Clin. Cancer Res. 1 (1995), 591-598.

[10] R. de Bree, J.C. Ross, J.J. Quak, W. den Hollander, A.J. Wilhelm, A.van Lingen and G.B. Snow, Biodistribution of radiolabeled monoclonal antibody E48 IgG and $\mathrm{F}\left(\mathrm{ab}^{\prime}\right)-2$ in patients with head and neck cancer, Clin. Cancer Res. 1 (1995), 277286. 
[11] M.A.M. van den Brekel, H.V. Stel, P. van der Valk, I. van der Waal, C.J.L.M. Meyer and G.B. Snow, Micrometastases from squamous cell carcinoma in neck dissection specimens, Eur. Arch. Otorhinolaryngol. 249 (1992), 349-353.

[12] M.A.M. van den Brekel, I. van der Waal, C.J.L.M. Meyer, J.L. Freeman, J.A. Castelijns and G.B. Snow, The incidence of micrometastases in neck dissection specimens obtained from elective neck dissections, Laryngoscope 106 (1996), 987-991.

[13] J. A. Brennan, L. Mao, R.H. Hruban, J.O. Boyle, Y.J. Eby, W.M. Koch, S.N. Goodman and D. Sidransky, Molecular assessment of histopathological staging in squamous-cell carcinoma of the head and neck, N. Engl. J. Med. 332 (1995), 429435.

[14] J.A. Brennan and D. Sidransky, Molecular staging of head and neck squamous carcinoma, Cancer Metastasis Rev. 15 (1996), 3-10.

[15] M. Bryne, Is the invasive front of an oral carcinoma the most important area for prognostication?, Oral Dis. 4 (1998), 70-77.

[16] M. Bryne, M. Boysen, C.G. Alfsen, V.M. Abeler, J. Sudbo, J.M. Nesland, G.B. Kristensen, J. Piffko and A. Bankfalvi, The invasive front of carcinomas. The most important area for tumour prognosis?, Anticancer Res. 18 (1998), 4757-4764.

[17] M. Bryne, H.S. Koppang, R. Lilleng and A. Kjaerheim, Malignancy grading of the deep invasive margins of oral squamous cell carcinomas has high prognostic value, J. Pathol. 166 (1992), 375-381.

[18] A. Chadburn, G. Inghirami and D.M. Knowles, The kinetics and temporal expression of T-cell activation-associated antigens CD15 (LeuM1), CD30 (Ki-1), EMA and CD11c (LeuM5) by benign activated T cells, Hematol. Pathol. 6 (1992), 193202.

[19] W.H. Clark Jr, The nature of cancer: Morphogenesis and progressive (self)-disorganization in neoplastic development and progression, Acta Oncol. 34 (1995), 3-21.

[20] J.L. Cordell, B. Falini, W.N. Erber, A.K. Ghosh, Z. Abdulaziz, S. MacDonald, K.A.F. Pulford, G. Stein and D.Y. Mason, Immunoenzymatic labeling of monoclonal antibodies using immune complexes of alkaline phosphatase and monoclonal antialkaline phosphatase (APAAP complexes), J. Histochem. Cytochem. 32 (1984), 219-229.

[21] R.J. Cote, C. Taylor and A.M. Neville, Detection of occult metastases, Cancer J. 8 (1995), 49-51.

[22] G.A. Dent, C.J. Civalier, M.E. Brecher and S.A. Bentley, MUC1 expression in hematopoietic tissues, Am. J. Clin. Pathol. 111 (1999), 741-747.

[23] I.J. Diel and G. Bastert, "Minimal residual disease" beim Mammakarzinom, in: Onkologie: Gundlagen - Diagnostik - Therapie - Entwicklungen, W.J. Zeller and H. zur Hausen, eds, ecomed Verlagsgesellschaft AG \& Co KG; 1995; 5. Erg. Lfg. (1998), II-9, 1-14.

[24] G.A.M.S. van Dongen, R.M. Brakenhoff, C. ten Brink, F.B. van Gog, R. de Bree, J.J. Quak and G.B. Snow, Squamous cell carcinoma-associated antigens used in novel strategies for the detection and treatment of minimal residual head and neck cancer, Anticancer Res. 16 (1996), 2409-2414.

[25] G.A.M.S. van Dongen, H. Leverstein, J.C. Roos, J.J. Quak, M.W. van den Brekel, A. van Lingen, H.J. Martens, J.A. Castelijns, G.W. Visser and C.J. Meijer, Radioim- munoscintigraphy of head and neck cancer using ${ }^{99} \mathrm{mTc}-$ labeled monoclonal antiboddy $\mathrm{E} 48 \mathrm{~F}\left(\mathrm{AB}^{\prime}\right)_{2}$, Cancer Res. 52 (1992), 2569-2574.

[26] E.-M. Fabricius, M. Guschmann, G.P. Wildner, A. Langford, B. Hell and J. Bier, Divergent immunohistochemical E48 and CD44-v6 antigen expression patterns between lymph node metastases and primary squamous cell carcinomas in the headneck region, Cancer J. 11 (1998), 153-159.

[27] E.-M. Fabricius, A. Langford, J. Bier, B. Hell, G.P. Wildner and S.Blümcke, Immunohistochemical characterization of E48 and CD44-v6 expression in head and neck carcinomas, Cancer J. 10 (1997), 325-330.

[28] I.J. Fidler, Origin and biology of cancer metastasis, Cytometrie 10 (1989), 673-680.

[29] I.J. Fidler, Host and tumour factors in cancer metastasis, European J. Clin. Investigation 20 (1990), 481-486.

[30] H.J. Gath and R.H.Brakenhoff, Minimal residual disease in head and neck cancer, Cancer and Metastasis Reviews 18 (1999), 109-126.

[31] U. Günthert, CD44: A multitude of isoforms with diverse functions, Current Topics in Microbiol. and Immunol. 184 (1993), $47-63$.

[32] U. Günthert, M. Hofmann, W. Rudy, S. Reber, M. Zöller, I. Haußmann, S. Matzku, A. Wenzel, H. Ponta and P. Herrlich, A new variant of glycoprotein CD44 confers metastatic potential to rat carcinoma cells, Cell 65 (1991), 13-24.

[33] B.A. Gusterson and R. Ott, Occult axillary lymph-node micrometastases in breast cancer. Comment to: Prognostic importance of occult axillary lymph node micrometastases from breast cancers. International (Ludwig) Breast Cancer Study group, Lancet 336 (1990), 434-435.

[34] N.L.W. van Hal, G.A.M.S. van Dongen, E.M.C. RoodKnippels, P. van der Valk, G.B. Snow and R.H. Brakenhoff, Monoclonal antibody U36, a suitable candidate for clinical immunotherapy of squamous-cell carcinoma, recognizes a CD44 isoform, Int. J. Cancer 68 (1996), 520-527.

[35] C. Herold-Mende, S. Seiter, A.I. Born, E. Patzelt, M. Schupp, J. Zöller, F.X. Bosch and M. Zöller, Expression of CD44 splice variants in squamous epithelia and squamous cell carcinomas of the head and neck, J. Path. 179 (1996), 66-73.

[36] P. Hyckel, H. Kosmehl, A. Berndt, J. Hesse, K.-J. Stiller and Ch. Robotta, Immunohistochemische Demonstration von CD $44 \mathrm{H}, \mathrm{CD} 44$ v3 und CD 44 v6 im oralen Plattenepithelkarzinom, Dtsch. Z. Mund Kiefer GesichtsChir. 19 (1995), 284-289.

[37] J.R. Izbicki, B. Passlick, S.B. Hosch, B. Kubuschok, C. Schneider, W.T. Knoefel, O. Thetter and K. Pantel, Mode of spread in the early phase of lymphatic metastasis in non-small-cell lung cancer: Significance of nodal micrometastasis, J. Thorac. Cardiovasc. Surgery 112 (1996), 623-630.

[38] A.S. Jones, D.E. Phillips, T.R. Helliwell and N.J. Roland, Occult node metastases in head and neck squamous carcinoma, Eur. Arch. Otorhinolaryngol. 250 (1993), 446-449.

[39] A.R. Kagan and T.-L. Morgan, Subclinical disease revisited, Amer. J. Clin. Oncol. Cancer Clin. Trials 22 (1999), 621-626.

[40] S. Kita, T. Tsuda, K. Sugisaki, E. Miyazaki and T. Matsumoto, Characterization of distribution of T lymphocyte subsets and activated T lymphocytes infiltrating into sarcoid lesions, Internal Medicine 34 (1995), 847-855. 
[41] E.C. Kohn, Development and prevention of metastasis, Anticancer Research 13 (1993), 2553-2560.

[42] G. Koopman, A.W. Griffioen, H. Ponta, P. Herrlich, F. van den Berg, E. Manten-Horst and S.T. Pals, CD44 splice variants; Expression on lymphocytes and in neoplasia, Res. Immunol. 144 (1993), 750-754.

[43] S. Koscielny, M. Tubiana and A.-J. Valleron, A simulation model of the natural history of human breast cancer, Br. J. Cancer 52 (1985), 515-524.

[44] H. Kuwano, H. Saeki, H. Kawaguchi, K. Sonoda, K. Kitamura, H. Nakashima, Y. Toh and K. Sugimachi, Proliferative activity of cancer cells in front and center areas of carcinoma in situ and invasive sites of esophageal squamous-cell carcinoma, Int. J. Cancer 78 (1998), 149-152.

[45] M. Lagrange, J.M. Ferrero, J.L. Lagrange, J.C. Machiavello, J. Monticelli, C. Bayle, A. Creisson, M. Namer, A. Thyss, C. Bourcier, J. Gioanni and M. Schneider, Non-specifically labelled cells that simulate bone marrow metastases in patients with non-metastatic breast cancer, J. Clin. Pathol. 50 (1997), 206-211.

[46] J.D. Laman, C.B. Maassen, M.M. Schellekens, L. Visser, M. Kap, E. de Jong, M. van Puijenbroek, M.J. van Stipdonk, M. van Meurs, C. Schwarzler and U. Günthert, Therapy with antibodies against CD40L (CD154) and CD44-variant isoforms reduces experimental autoimmune encephalomyelitis induced by a proteolipid protein peptide, Mult. Scler. 4 (1998), 147-153.

[47] N. Maitre, J.M. Brown, M. Demcheva, J.R. Kelley, M.A. Lockett, J. Vournakis and D.J. Cole, Primary T-cell and activated macrophage response associated with tumor protective using peptide/poly-N-acetyl glucosamine vaccination, Clinical Cancer Res. 5 (1999), 1173-1182.

[48] J.N. Myers, The use of biological therapy in cancer of the head and neck, Curr. Probl. Cancer 23 (1999), 106-134.

[49] T. Osaki, J. Hirota, K. Yoneda, T. Yamamoto and E. Ueta, Clinical and histopathologic characteristics of tongue and gingiva carcinomas with occult and clinically evident cervical lymphnode metastasis, Int. J. Oral Maxillofac. Surg. 25 (1996), 274 278.

[50] S.T. Pals, G. Koopman, K.H. Heider, A. Griffioen, G.R. Adolf, F. van den Berg, H. Ponta, P. Herrlich and E. Horst, CD44 splice variants: expression during lymphocyte activation and tumor progression, Behring Inst. Mitt. 92 (1993), 273-277.

[51] K. Pantel, R.J. Cote and O. Fodstad, Detection and clinical importance of micrometastatic disease, J. Natl. Cancer Inst. 91 (1999), 1113-1124.

[52] K. Pantel and G.Riethmüller, Methods for detection of micrometastatic carcinoma cells in bone marrow, blood and lymph node, Onkologie 18 (1995), 394-401.

[53] K. Pantel, M. von Knebel-Doeberitz, J.R. Izbicki and G. Riethmüller, Disseminated tumor cells: diagnosis, prognostic relevance, phenotyping and therapeutic strategies, Chirurg 68 (1997), 1241-1250.

[54] D.M. Parkin, P. Pisani and J. Ferlay, Global cancer statistics, CA Cancer J. Clin. 49 (1999), 33-64.

[55] B. Passlick, J.R. Izbicki, B. Kubuschok, W. Nathrath, O. Thetter, U. Pichlmeier, L. Schweiberberer, G. Riethmüller and K. Pantel, Immunohistochemical assessment of individual tumor cells in lymph nodes of patients with non-small-cell lung cancer, J. Clin. Oncology 12 (1994), 1827-1832.
[56] J. Piffko, A. Bankfalvi, U. Joos, D. Ofner, M. Krassort and K.W. Schmid, Immunophenotypic analysis of normal mucosa and squamous cell carcinoma of the oral cavity, Cancer Detection Prevention 23 (1999), 45-56.

[57] J. Piffko, A. Bankfalvi, K. Klauke, R. Dreier, U. Joos, W. Böcker and K.W. Schmid, Unaltered strong immunohistochemical expression of CD44 v6 and v5 isoforms during development and progression of oral squamous cell carcinomas, J. Oral Pathol. Med. 25 (1996), 502-506.

[58] J. Piffko, A. Bankfalvi, D. Ofner, M. Bryne, D. Rasch, U. Joos, W. Bocker and K.W. Schmid, Prognostic value of histobiological factors (malignancy grading and AgNOR content) assessed at the invasive tumour front of oral squamous cell carcinomas, Br. J. Cancer 75 (1997), 1543-1546.

[59] J. Piffko, A. Bankfalvi, D. Ofner, F. Kusch, W. Bocker, U. Joos and K.W. Schmid, In situ assessment of cell proliferation at the invasive front of oral squamous cell carcinomas, Virchows Arch. Intern. J. Pathol. 429 (1996), 229-234.

[60] J. Piffko, A. Bankfalvi, K. Tory, L. Fuzesi, M. Bryne, D. Ofner, F. Kusch, U. Joos and K.W. Schmid, Molecular assessment of p53 abnormalities at the invasive front of oral squamous cell carcinomas, Head and Neck 20 (1998), 8-15.

[61] P. Pouillart, Le concept de micrometastase, Sem. Hop. Paris. 71 (1995), 997-999.

[62] J.J. Quak, A.A.J.M. Balm, J.G.P. Brakkee, R.J. Scheper, C.J.L.M. Meijer and G.B. Snow, Production of monoclonal antibodies to squamous cell carcinoma antigens, Arch. Otolaryngol. Head Neck Surg. 116 (1990), 181-185.

[63] J.J. Quak, A.J.M. Balm, G.A.M.S. van Dongen, J.G.P. Brakkee, R.J. Scheper, G.B. Snow and C.J.M. Meijer, A 22-kd surface antigen detected by monoclonal antibody $\mathrm{E} 48$ is exlusively expressed in stratified squamous and transitional epithelia, Am.J. Pathol. 136 (1990), 191-197.

[64] D. Ravi, K.R. Nalinakumari, R.S. Rajaram, M. Krishnan-Nair and M. Radhakrishna-Pillai, Expression of programmed cell death regulatory p53 and bcl-2 proteins in oral lesions, Cancer Letters 105 (1996), 139-146.

[65] W. Remmele and H.E. Stegner, Vorschlag zur einheitlichen Definition eines immunreaktiven Score (IRS) für den immunhistochemischen Östrogenrezeptor-Nachweis (ER-ICA) im Mammagewebe, Pathologe 8 (1987), 138-140.

[66] L. Sachs, Angewandte Statistik, 7 Aufl., Springer, Berlin, 1992, pp. 846.

[67] M. Salmi, K. Grön-Virta, P. Sointu, R. Grenman, H. Kalimo and S. Jalkanen, Regulated expression of exon v6 containing isoforms of CD44 in man: downregulation during malignant tranformation of tumors of squamocellular origin, J. Cell Biol. 122 (1993), 431-442.

[68] A.H.G.J. Schrijvers, M. Gerretsen, J.M. Fritz, M. van Walsum, J.J. Quak, G.B. Snow and G.A.M.S. van Dongen, Evidence for a role of the monoclonal antibody E48 defined antigen in cellcell adhesion in squamous epithelia and head and neck squamous cell carcinoma, Exper. Cell Res. 196 (1991), 264-269.

[69] J.P. Sloane, Molecules and micrometastases, Lancet 345 (1995), 1255-1256

[70] M.W. Sung, S. Nagashima, J.T. Johnson, G.A. Van Dongen and T.L. Whiteside, The role of apoptosis in antibody-dependent cell-mediated cytotoxicity against monolayers of human squamous cell carcinoma of the head and neck targets, Cell. Immunol. 171 (1996), 20-29. 
[71] R.P. Takes, R.J.B. de Jong, E. Schuuring, J. Hermans, A.A. Vis, S.V. Litvinov and H.J.M. van Krieken, Markers for assessment of nodal metastasis in laryngeal carcinoma, Arch. Otolaryngol. Head Neck Surg. 123 (1997), 412-419.

[72] A.R. Vora, S. Rodgers, A.J. Parker, R. Start, R.C. Rees and A.K. Murray, An immunohistochemical study of altered immunomodulatory molecule expression in head and neck squamous cell carcinoma, Brit. J. Cancer 76 (1997), 836-844.

[73] L. Weiss, Metastatic inefficiency, Advances Cancer Res. 54 (1990), 159-211.
[74] B. Wittig, C. Schwärzler, N. Fohr, U. Günthert and M. Zöller, Curative treatment of an experimentally induced colitis by a CD44 variant v7-specific antibody, J. Immunol. 161 (1998), 1069-1073.

[75] B. Wittig, S. Seiter, N. Föger, C. Schwärzler, U. Günthert and M. Zöller, Functional activity of murine CD44 variant isoforms in allergic and delayed type hypersensitivity, Immunology Letters 57 (1997), 217-223. 


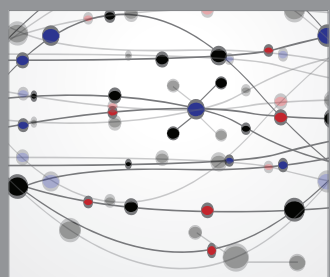

The Scientific World Journal
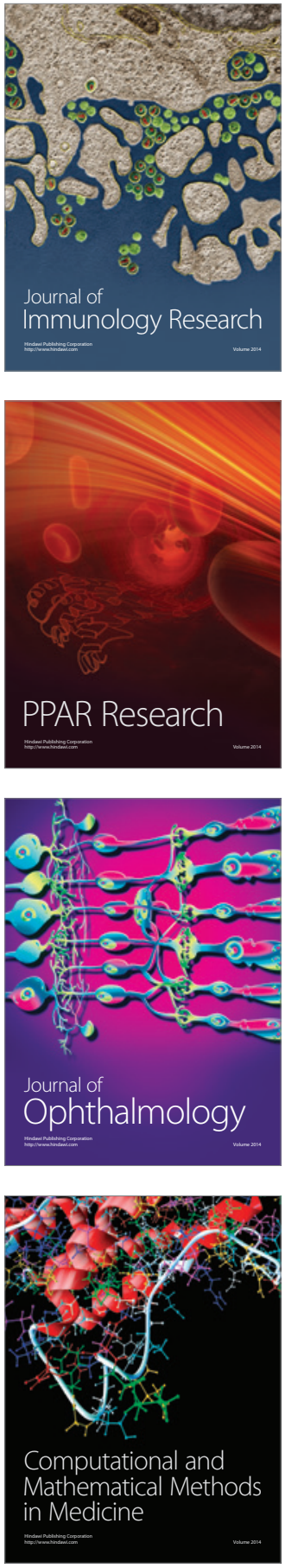

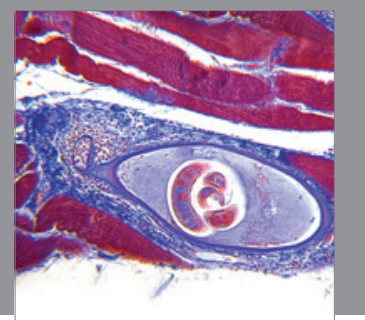

Gastroenterology

Research and Practice
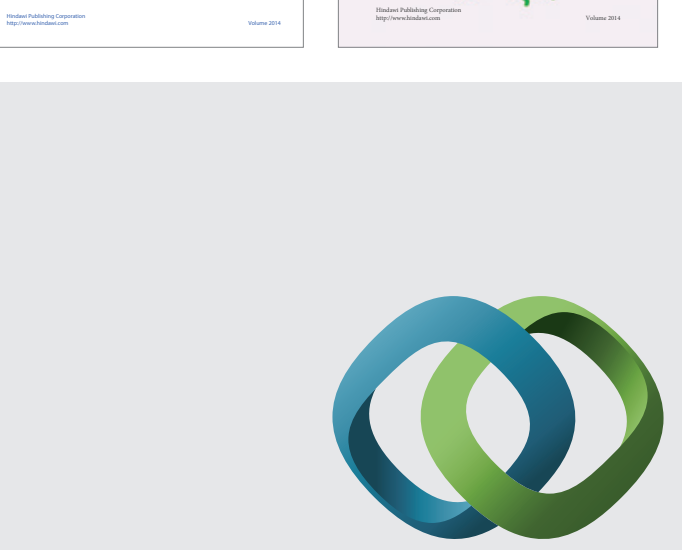

\section{Hindawi}

Submit your manuscripts at

http://www.hindawi.com
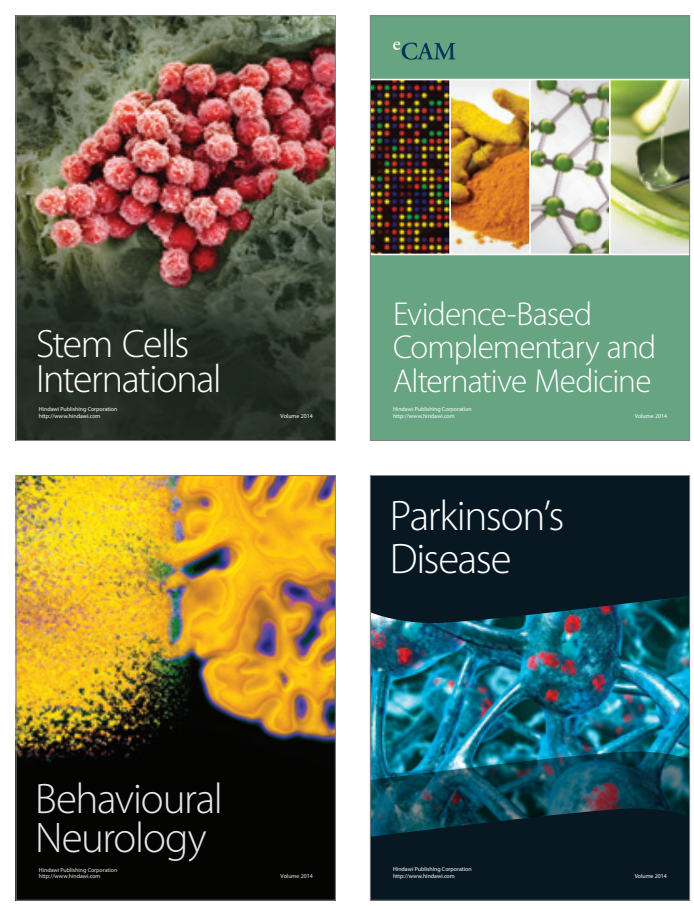

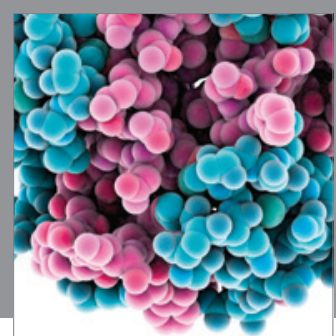

Journal of
Diabetes Research

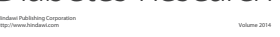

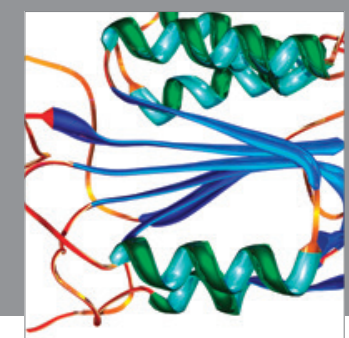

Disease Markers
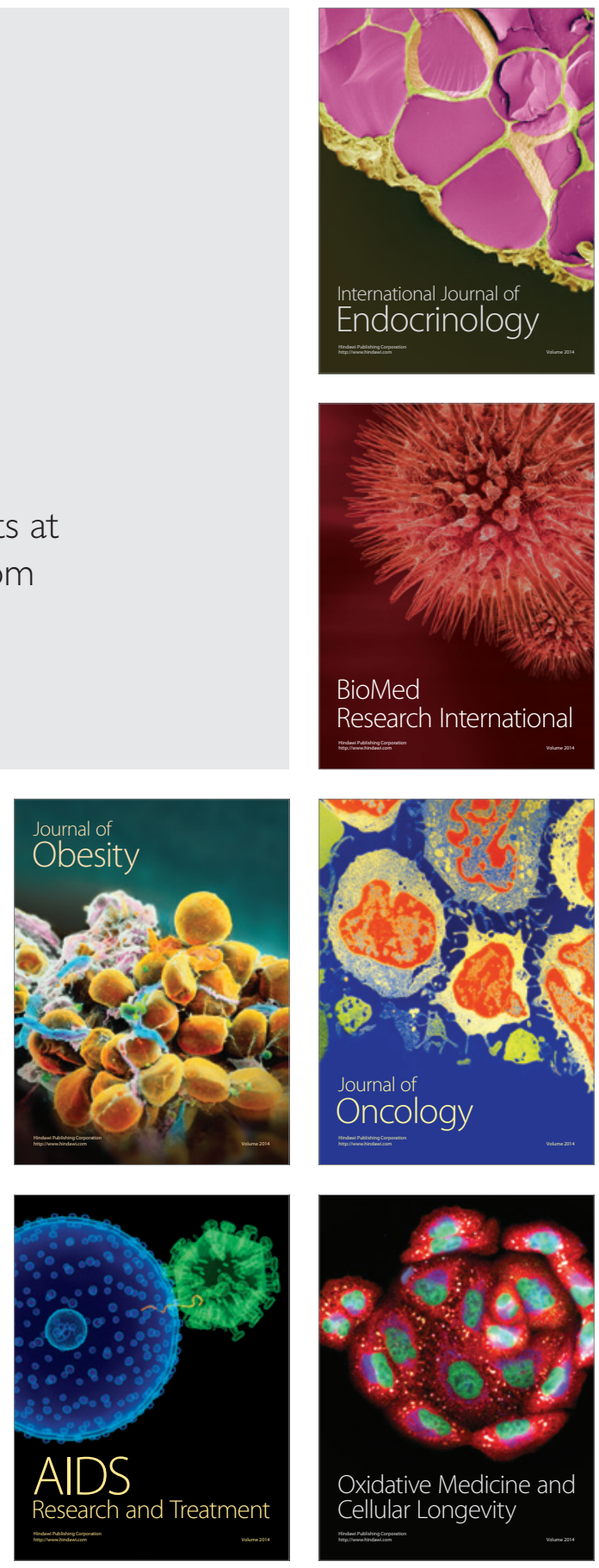